\title{
EDITORIAL NOTE TO LORD HAILSHAM'S "LECTURE ON THE LAW OFFICERS AND THE LORD CHANCELLOR"*
}

\footnotetext{
* Prepared by David Kilgour, senior Crown attorney, Department of the Alberta Attorney General, member of the bars of Alberta, British Columbia and Manitoba, for the Editorial Board of the Alberta Law Review.
}

1. Canada has no single person equivalent to Britain's unique Lord Chancellor on either the federal or provincial level. His role as Speaker of the House of Lords, for instance, in the federal government is held by our Speaker of the Senate; as formal medium of communication between the Sovereign and Parliament, by our Governor General and Prime Minister; as political head of the judiciary, by no one; and as the effective appointer of senior judges, by our Governor-in-Council on the recommendation of our Minister of Justice and/or Prime Minister. Nor does any member of our federal cabinet preside over any court, as does the Lord Chancellor over the House of Lords sitting as Britain's highest court of appeal.

2. The Chancellor of the Exchequer's main responsibility is government financial policy, including its budget, so his role most closely parallels our Minister of Finance. It also appears to include the duties of the separate Canadian minister who is President of the Treasury Board and advises the cabinet on the best use of tax monies in government programs. The comparable minister on the provincial level is either the Provincial Treasurer or Minister of Finance.

3. Canada lacks regional law officers, of course, within the Federal cabinet. Being a federal state unlike Britain, the provincial Attornies General fulfill the same role as the Attorney General of Canada in the provincial spheres.

4. Nothing in the Department of the Solicitor General Act, 1970 R.S.C. CS - 12, requires its minister to be a lawyer, although all of them appear to have been since 1966 when the department was created. Before 1936, the Solicitor General has no department; from 1936 - 1945 his duties were wholly absorbed by the Attorney General of Canada. In 1945, legislation re-established him as a cabinet officer to "assist the Minister of Justice in the counsel work of the Department of Justice". Since 1966, the primary responsibility has been in the fields of correction and law enforcement, and he is responsible for the R.C.M.P., the Canadian Penitentiary Service, and the National Parole Board. The Attornies General of both our federal and provincial governments need not be lawyers but invariably have been since one's mind runneth not to the contrary. An exception was former premier E.C. Manning who, although not legally trained, became Attorney General of Alberta as well as premier in 1955. The present Solicitor General of Alberta, the Hon. Roy Farran, is not a lawyer.

5. Our federal Minister of Justice (or Attorney General of Canada) and his department provide legal services to his government and its various departments, superintends the administration of justice not within provincial jurisdiction, and either administers or maintains a special interest in about 35 federal statutes. Provincial Attornies 
General (occasionally also called Ministers of Justice) have equivalent responsibilities in areas of provincial authority, being normally responsibile for both court administration (including provincially established courts and S.96 BNA Act provincial courts). Provincial appointments to courts appear to be primarily the responsibility of Attornies General in most provinces, although they are formally effected by order-in-council of the Lieutenant Governor-in-Council. Prosecutions under the Criminal Code and all provincial statutes are under the general direction of the respective provincial Attornies General, although they are normally begun by his Crown attornies without reference to him. In some provinces, the Attorney General still maintains responsibility for corrections and law enforcement, as well.

6. Alberta separated the corrections and law enforcement functions with the enactment of its Department of the Solicitor Gneral Act, 1973 S.A. C-67, although interestingly by S.3 of that act the Alberta Solicitor General's powers are those "attached to the office of the Solicitor General of England by law or usage ....". It is, in fact, the function of the Home Secretary in Britain to supervise police generally as is the principal role, along with corrections, of the Alberta Solicitor General.

7. Prosecutions in Canada appear to be more centralized. Fulltime law enforcement people employed by one or the other of the two senior levels of government normally act as informants, although victims themselves are occasionally (too often, say some) asked to be informants. Provincial Crown Attornies normally conduct cases under provincial and municipal statutes as well as the Criminal Code and by agreement under other federal statutes. Currently, there is an informal federal-provincial agreement in Alberta that where one individual is charged under both the Code and another federal act, whichever "Crown" has the heavier side will do both parts of the case. Private citizens are entitled as of right to swear complaints under S.455.3 of the Code, but the receiving justice may, having heard the allegations under oath, decline to issue a summons to the accused. Nolle Prosequi is available by S.508(2) of the Code.

8. The situation would appear to be the same for federal and provincial Attornies General in Canada. The recently-begun prosecution of the Toronto Sun newspaper under the Official Secrets Act of Canada would appear on the surface to have been a decision of Justice Minister Basford alone.

9. To my knowledge, the federal Attorney General does not personally appear in the courts except by agents. Some of the provincial Attornies General have done so. Roy McMurtry, Attorney General of Ontario, appeared as one of three counsel for his province before Canada's Supreme Court on the Anti-Inflation Reference (1976) 2 S.C.R. 373.

10. Evidently, not so in Canada at both federal and provincial levels. In 1933, for instance, $33.1 \%$ of Parliament's seats were held by lawyers, leading or otherwise; the proportion does not seem to have changed appreciably in recent years. 